\title{
EMPLOYEE ENGAGEMENT: A COMPREHENSIVE LITERATURE REVIEW
}

\section{MANISH BHALLA}

Jagannath University, India

\begin{abstract}
Despite the apparent importance of engagement, relatively little academic research has been conducted in this area. Most of the references relate to work done by survey houses and consultancies. The verb 'to engage' has a variety of meanings, ranging from straightforward and transactional (to hire someone to do a job), to exciting and mysterious (to fascinate and charm). The closest relationship with engagement is the type of commitment known as 'affective'. This type of commitment emphasizes the satisfaction people get from their jobs and their colleagues, and the willingness of employees to go beyond the call of duty for the good of the organization. It also goes some way towards capturing the two-way nature of the engagement relationship, as employers are expected to provide a supportive working environment. Research shows that committed employees perform better. If we accept that engagement, as many believe, is 'one-step up' from commitment, it is clearly in the organization's interests to understand the drivers of engagement as well.
\end{abstract}

KEYWORDS: Positive Affectivity, Job Satisfaction, Connection, Two-Way Nature \& Effective Management

Received: Mar 16, 2018; Accepted: Apr 06, 2018; Published: Apr 21, 2018; Paper Id.: IJHRMRJUN20181

\section{INTRODUCTION}

Employee engagement has been the focus of growing interest in recent years as research in positive organizational phenomena has expanded. Establishing an engaged workforce is now a high priority for many organizations in both private and public sectors. To win customers and a bigger share of the marketplace companies must first win the hearts and minds of their employees. In the context of changing workforce demographics and increasing demand for responsive services, employee engagement is essential to retain committed, productive employees. Many employers feel that engaged employees outperform others by showing heightened interest in their work and being prepared to 'go the extra mile' and exerting discretionary effort for their organization.

Employee engagement is a vast construct that touches almost all parts of human resource management facets we know hitherto. The construct employee engagement is built on the foundation of earlier concepts like job satisfaction, employee commitment and organizational citizenship behavior although it encompasses these concepts and is broader in scope.

Literature across disciplines lacks congruence in defining engagement. What is common to these definitions is the active use of cognition, emotions, and behaviors in engagement.

Kahn (1990) found that a person's level of engagement was a function of the experience of three psychological conditions: psychological meaningfulness, psychological safety, and psychological availability. He found that the work that is experienced as challenging, clearly delineated, varied, creative, and autonomous is most likely to be associated with the experience of psychological meaningfulness. He also found that psychological safety was influenced by interpersonal relationships, group and intergroup dynamics, management styles and 
processes, and organizational norms. Lastly, he found that psychological availability was negatively influenced by depletion of physical, emotional and psychological resources required to invest one's self in the performance of the role. Robinson et al. (2004) defines employee engagement as "a positive attitude held by the employee towards the organization and its value. An engaged employee is aware of business context, and works with colleagues to improve performance within the job for the benefit of the organization." According to Vance (2006), Employee engagement is the outcome of personal attributes such as knowledge, skills, abilities, temperament, attitudes and personality, organizational context which includes leadership, physical setting and social setting and HR practices that directly affect the person, process and context components of job performance. Employee engagement is defined as the employees' level of positive affectivity, which is characterized by attention, absorption, dedication, participation, vigor, enthusiasm, excitement, and pride in occupying and performing an organizational role (Saks, 2006); and their level of physiological empowerment, which is characterized by their sense of competence or self-efficacy, control, autonomy, meaningfulness, and influence (Kang, 2010). Positive affectivity echoes existing definitions of employee engagement and thus represents a central component of the engagement construct (Kang, 2010). Engagement is about passion and commitment-the willingness to invest oneself and expand one's discretionary efforts to help the employer succeed, which is beyond simple satisfaction with the employment arrangement or basic loyalty to the employer (Blessing White, 2008; Macey and Schnieder, 2008). Alfes et al. (2013) showed a positive association between perceived HRM practices and employee engagement in two independent samples.

\section{METHODOLOGY}

This literature review examines the general sentiment of the literature and the evidence available across the various sectors of the organization in terms of its definition and historical development. It also aims at understanding employee engagement in the field of academics and the extent to which it varies compared to the consultancy or research institutions and companies.

Methodology for the literature review has been structured in four phases as follows:

- Search process through which the potentially relevant literature was identified.

- Screening process for review of documentation to derive the most relevant and pertinent publications.

- Analysis process through which the literature was analyzed.

- Documentation process through which the literature was logically and schematically organized.

\section{MEANING, DEFINITIONS AND CHARACTERISTICS}

The purpose of this section is to review what employee engagement means in the literature in order to identify if a clear and common idea of what engagement is can be drawn out. The literature on employee engagement builds on earlier research and discussion on issues of commitment and organizational behavior, but means more than what these terms encapsulate. Next this section discusses the definitions of employee engagement throughout the literature resulting in highlighting the key factors by which an engaged workforce can be identified.

Kahn (1990) referred to engagement as a situation where people express themselves physically, cognitively and emotionally during work role performance. Hay Group (2001) says engagement is comprised of two components: 
Commitment - affective attachment to and intention to remain with an organization and Discretionary Effort - the willingness to go above and beyond formal job requirements. Schaufeli and Bakker (2003) described employee engagement as "A sense of energetic and effective connection of employees with their work activities and they see themselves as able to deal well with the demands of their job". Towers Perrin (2003) believes that engagement involves both 'emotional and rational factors relating to work and the overall work experience. Blizzard (2004) Gallup suggested that engaged employees are 'psychologically committed to their work, go above and beyond their basic job expectations, and want to play a key role in fulfilling the mission of their organizations'. Baumruk and Marusarz (2004) Hewitt Associates suggest that engaged employee stay, say and drive. In other words, engaged employees 'have an intense desire to be members of the organization ... are passionate advocates for their workplace ... they refer potential employees and customers they go beyond what is minimally required to produce extraordinary service and results for customers and colleagues'. Shaw (2005) defines employee engagement as 'translating employee potential into employee performance and business success" and thus "changing the way employees perform by utilizing the tools in the armory of internal communication professionals". Vance (2006) Dell Inc. defines employee engagement by stating, “To compete today, companies need to win over the minds (rational commitment) and the hearts (emotional commitment) of employees in ways that lead to extraordinary effort”. Catteeuw et al. (2007) Johnson and Johnson says engaged employees will stay with the company longer and continually find smarter, more effective ways to add value to the organization. Mercer (2007) says engagement is the result of how employees feel about the work experience - the organization, its leaders, the work and the work environment. CIPD (2007) suggests engagement goes beyond job satisfaction and is not simply the motivation. Engagement is something the employee has to offer: it cannot be 'required' as part of the employment contract'. Fleming and Asplund (2007) of Gallup point out that engaged employees want their organization to succeed because they feel connected emotionally, socially, and even spiritually to its mission, vision, and purpose. Pritchard (2008) described employee engagement in terms of "Say, Stay, Strive" where say means how employees talk about their organization with others whereas stay stands for commitment and loyalty of employees and strive means employees are willing to do anything for their organization. Suff (2008) Vodaphone defines employee engagement as 'an outcome "measured or seen as a result of people being committed to something or someone in the business - a very best effort that is willingly given".' Macey and Schneider (2008) Engagement have variously been conceived as a psychological or affective state (e.g. commitment, involvement, attachment, etc.), a performance constructs (e.g. role performance, effort, observable behavior, organizational citizenship behavior etc.). Barclays (2008) defines employee engagement might be, 'the extent to which an employee feels a sense of attachment to the organization he or she works for, believes in its goals and supports its values.' Nokia Siemens Networks (2008) describes being engaged as 'an emotional attachment to the organization, pride and a willingness to be an advocate of the organization, a rational understanding of the organization's strategic goals, values, and how employees fit and motivation and willingness to invest discretionary effort to go above and beyond'. Blessing White (2008) defines full engagement as pertaining to 'maximum job satisfaction' and 'maximum job contribution'. Truss et al (2009) says engagement is also about creating an environment where employees are motivated to want to connect with their work and really care about doing a good job. Schuck and Wollard (2010) defined employee engagement as an “individual employee's cognitive, emotional and behavioral state directed towards desired organizational outcomes. Cook (2012) define engagement as "how positively the employee thinks about organization, feels about the organization and is proactive in relation to achieving organizational goals for customers, colleagues and other stakeholders". Truss et al (2013) suggested that "engagement may constitute the mechanism through which HRM practitioners impact individual and organizational performance'. 
Table 1: Characteristics Defining Employee Engagement

\begin{tabular}{|c|c|c|}
\hline $\begin{array}{c}\text { Definition } \\
\text { Characteristic }\end{array}$ & Description & Sources \\
\hline $\begin{array}{l}\text { Emotional } \\
\text { Engagement }\end{array}$ & $\begin{array}{l}\text { A situation where people express themselves physically, } \\
\text { cognitively and emotionally during work role performance. }\end{array}$ & (Kahn, 1990) \\
\hline $\begin{array}{l}\text { Commitment \& } \\
\text { Discretionary } \\
\text { Behavior }\end{array}$ & $\begin{array}{l}\text { Engagement is comprised of two components: } \\
\text { Commitment }- \text { affective attachment to and intention to } \\
\text { remain with an organization and Discretionary Effort }- \text { the } \\
\text { willingness to go above and beyond formal job } \\
\text { requirements. }\end{array}$ & $\begin{array}{l}\text { Hay } \\
(2001)\end{array}$ \\
\hline Connection & $\begin{array}{l}\text { "A sense of energetic and effective connection of } \\
\text { employees with their work activities and they see } \\
\text { themselves as able to deal well with the demands of their } \\
\text { job". }\end{array}$ & $\begin{array}{l}\text { Schaufeli and } \\
\text { Bakker (2003) }\end{array}$ \\
\hline $\begin{array}{l}\text { Effective } \\
\text { Management }\end{array}$ & $\begin{array}{l}\text { The top three among the ten drivers listed by Perrin are: } \\
\text { Senior management's interest in employees' well being, } \\
\text { Challenging work and Decision making authority. }\end{array}$ & $\begin{array}{lr}\text { Towers } & \text { Perrin } \\
\text { Talent } & \text { Report } \\
(2003) & \end{array}$ \\
\hline $\begin{array}{l}\text { Two-way } \\
\text { relationship } \\
\text { between } \\
\text { employee and } \\
\text { employer }\end{array}$ & $\begin{array}{l}\text { It is two-way nature, and the extent to which engaged } \\
\text { employees are expected to have an element of business } \\
\text { awareness. }\end{array}$ & $\begin{array}{l}\text { Robinson et al. } \\
(2004)\end{array}$ \\
\hline Commitment & $\begin{array}{l}\text { Engaged employees are 'psychologically committed to } \\
\text { their work, go above and beyond their basic job } \\
\text { expectations, and want to play a key role in fulfilling the } \\
\text { mission of their organizations. }\end{array}$ & Blizzard (2004) \\
\hline $\begin{array}{l}\text { Passion for work } \\
\& \text { Commitment }\end{array}$ & $\begin{array}{l}\text { 'The energy, passion or "fire in the belly" employees have } \\
\text { for their employer or more specifically what their employer } \\
\text { is trying to achieve in the market'. }\end{array}$ & $\begin{array}{l}\text { Baumruk and } \\
\text { Marusarz (2004) }\end{array}$ \\
\hline $\begin{array}{l}\text { Effective } \\
\text { Communication }\end{array}$ & $\begin{array}{l}\text { "Translating employee potential into employee } \\
\text { performance and business success" and thus "changing the } \\
\text { way employees perform by utilizing the tools in the armory } \\
\text { of internal communication professionals". }\end{array}$ & Shaw (2005) \\
\hline Commitment & $\begin{array}{l}\text { "To compete today, companies need to win over the minds } \\
\text { (rational commitment) and the hearts (emotional } \\
\text { commitment) of employees in ways that lead to } \\
\text { extraordinary effort". }\end{array}$ & Vance (2006) \\
\hline $\begin{array}{l}\text { Positive } \\
\text { Affectivity }\end{array}$ & Employees' level of positive affectivity. & (Saks, 2006) \\
\hline Satisfaction & $\begin{array}{l}\text { The degree to which employees are satisfied with their } \\
\text { jobs, feel valued, and experience collaboration and trust. }\end{array}$ & $\begin{array}{l}\text { Catteeuw et al. } \\
(2007)\end{array}$ \\
\hline Motivation & $\begin{array}{l}\text { 'A state of mind in which employees feel a vested interest } \\
\text { in the company's success and are both willing and } \\
\text { motivated to perform to levels that exceed the stated job } \\
\text { requirements. }\end{array}$ & Mercer (2007) \\
\hline $\begin{array}{l}\text { Commitment \& } \\
\text { Willingness }\end{array}$ & $\begin{array}{l}\text { "Can be seen as a combination of commitment to the } \\
\text { organization and its values plus a willingness to help out } \\
\text { colleagues (organizational citizenship). }\end{array}$ & CIPD (2007) \\
\hline Passion for work & $\begin{array}{l}\text { "The ability to capture the heads, hearts and souls of your } \\
\text { employees to instill an intrinsic desire and passion for } \\
\text { excellence." }\end{array}$ & $\begin{array}{l}\text { Fleming and } \\
\text { Asplund (2007) }\end{array}$ \\
\hline Say, stay, strive & $\begin{array}{l}\text { Employee engagement described in terms of "Say, Stay, } \\
\text { Strive". }\end{array}$ & Pritchard (2008) \\
\hline $\begin{array}{l}\text { Commitment and } \\
\text { Willingness }\end{array}$ & $\begin{array}{l}\text { "An outcome "measured or seen as a result of people being } \\
\text { committed to something or someone in the business - a } \\
\text { very best effort that is willingly given".' }\end{array}$ & Suff (2008) \\
\hline
\end{tabular}




\begin{tabular}{|c|c|c|}
\hline \multicolumn{3}{|c|}{ Table 1: Contd., } \\
\hline Performance & $\begin{array}{l}\text { Engagement has variously been conceived as a } \\
\text { psychological or affective state and a performance } \\
\text { construct. }\end{array}$ & $\begin{array}{l}\text { Macey } \\
\text { Schneider } \\
(2008)\end{array}$ \\
\hline Attachment & $\begin{array}{l}\text { 'The extent to which an employee feels a sense of } \\
\text { attachment to the organization. }\end{array}$ & Barclays (2008) \\
\hline $\begin{array}{l}\text { Motivation and } \\
\text { Discretionary } \\
\text { Behavior }\end{array}$ & $\begin{array}{l}\text { 'An emotional attachment to the organization. Motivation } \\
\text { and willingness to invest discretionary effort to go above } \\
\text { and beyond'. }\end{array}$ & $\begin{array}{l}\text { Nokia Siemens } \\
\text { Networks } \\
(2008)\end{array}$ \\
\hline $\begin{array}{l}\text { Satisfaction and } \\
\text { Contribution }\end{array}$ & $\begin{array}{l}\text { Engagement is pertaining to 'maximum job satisfaction' } \\
\text { and 'maximum job contribution'. }\end{array}$ & $\begin{array}{l}\text { Blessing White } \\
(2008)\end{array}$ \\
\hline $\begin{array}{l}\text { Passion for work } \\
\text { and Commitment }\end{array}$ & $\begin{array}{l}\text { Engagement is about passion and commitment to help the } \\
\text { employer succeed. }\end{array}$ & $\begin{array}{l}\text { (Blessing White, } \\
\text { 2008; Macey } \\
\text { and Schneider } \\
(2008)\end{array}$ \\
\hline Connection & $\begin{array}{l}\text { "Engagement is about creating opportunities for employees } \\
\text { to connect with their colleagues, managers and wider } \\
\text { organization. }\end{array}$ & $\begin{array}{l}\text { Truss et al } \\
(2009)\end{array}$ \\
\hline $\begin{array}{l}\text { Empowerment } \\
\text { and } \\
\text { Meaningfulness }\end{array}$ & $\begin{array}{l}\text { Level of physiological empowerment, which is } \\
\text { characterized by the sense of competence or self-efficacy, } \\
\text { control, autonomy, meaningfulness, and influence. }\end{array}$ & (Kang, 2010) \\
\hline $\begin{array}{l}\text { Emotional } \\
\text { Engagement }\end{array}$ & $\begin{array}{l}\text { "Individual employee's cognitive, emotional and } \\
\text { behavioral state directed towards desired organizational } \\
\text { outcomes. }\end{array}$ & $\begin{array}{l}\text { Schuck and } \\
\text { Wollard (2010) }\end{array}$ \\
\hline $\begin{array}{l}\text { Employee } \\
\text { identification } \\
\text { with the } \\
\text { organization }\end{array}$ & $\begin{array}{l}\text { "How positively the employee thinks about organization, } \\
\text { feels about the organization and is proactive in relation to } \\
\text { achieving organizational goals for customers, colleagues } \\
\text { and other stakeholders". }\end{array}$ & Cook (2012) \\
\hline $\begin{array}{l}\text { Managing } \\
\text { Performance }\end{array}$ & $\begin{array}{l}\text { 'Engagement may constitute the mechanism through which } \\
\text { HRM practitioners impact individual and organizational } \\
\text { performance'. }\end{array}$ & $\begin{array}{l}\text { Truss et } \\
(2013)\end{array}$ \\
\hline
\end{tabular}

\section{SUMMARY AND CONCLUSIONS}

It is concluded there is no universal definition on employee engagement however literature review is more or less consistent in its positive view of employee engagement and in that nature of engagement as a two-way interaction between employee and employer is emphasized in context of organizations. It must be noted that these conclusions are drawn within the context of type of literature available on the subject. With objective of finding common characteristics or concepts, thirty-five definitions were reviewed including those mentioned above and results are summarized in Table 3.1.

Engagement has been defined in numerous different ways by academic researchers, consultancy, research institutions, and companies. The definitions which are used are mostly about employees' emotions, feelings and psychological attitude about the work and the company. Engaged employees commit to the companies' values, feel fulfilled and enthusiastic in their work, they are focused and energized in their work.

\section{REFERENCES}

1. Kahn, W. A. (1990). Psychological Conditions of Personal Engagement and Disengagement at Work. Academy of Management Journal. 33, 692-724

2. Hay (2001). Engage employees and boost performance. www.haygroup.com/downloads/us/Engaged_Performance_120401.pdf

3. Schaufeli, W., \& Bakker, A. (2003). Utrecht Work Engagement Scale, Utrecht University, Preliminary Manual, Ver. 1. 
4. Perrin, T. (2003). Working Today: Understanding What Drives Employee Engagement The 2003 Towers Perrin Talent Report U. $S$ Report. [Online] Available: http://www.towersperrin.com/tp/getwebcachedoc? Webc = HRS/USA/2003/200309/Talent_2003.pdf(October 30, 2008)

5. Robinson, D., Perryman, S., \& Hayday, S. (2004), The Drivers of Employee Engagement Report 408, Institute for Employment Studies, $U K$

6. Blizzard, R. (2004). 'Engagement vs. satisfaction among hospital teams', Gallup Poll Tuesday Briefing, The Gallup Organisation, 9th March

7. Baumruk, R., \& Marusarz, T. (2004). Employee Engagement: Insights into Why It Matters and What You Can Do About It, Hewitt Associates LLC

8. Shaw, K. (2005). Employee engagement, how to build a high-performance workforce. Melcrum Publishing Limited, ISBN: 09547741

9. http://www.emeraldinsight.com/Insight/ViewContentServlet?Filename=Published/EmeraldFullTextArticle/Articles/050021070 1.html\#b15

10. Saks, A. M. (2006). Antecedents and consequences of employee engagement. Journal of Managerial Psychology, 21, 600-618

11. Vance, R. J. (2006). Employee engagement and commitment, A guide to understanding, measuring and increasing engagement in your organization. Society for Human Resource Management, 1-45.

12. Catteuw, F., Flynn, E., \& Vonderhorst, J. (2007). 'Employee engagement: boosting productivity in turbulent times', Organization Development Journal, 25 (2), 151-157

13. Mercer (2007). Exploring the Global Drivers of Employee Engagement, www.mercer.com/referencecontent.htm? idContent $=1281670$

14. CIPD (2007). Employee Engagement, www.cipd.co.uk/subjects/empreltns/general/empengmt.htm?IsSrchRes=1

15. Flemming, J.H., \& Asplund, J. (2007). Where employee engagement happens. The Gallup Management Journal at http:/gmj.gallup.com/content/102496/where-Employee-Engagement-Happens.aspx

16. Pritchard, K. (2008). Employee Engagement in the UK: Meeting the Challenge in the Public Sector. Development and Learning in Organizations. 22, 6, 15-17.

17. Suff, R. (2008). 'Vodaphone's entertaining employee-engagement strategy', IRS Employment Review, 896

18. Macey, W. H., \& Schneider, B. (2008). The meaning of employee engagement. Industrial and Organizational Psychology, 1 (2008), 3-30

19. Barclays(2008).Definition,www.business.barclays.co.uk/BRC1/jsp/brccontrol? task=articleFWvi6\&value=7220\&target $=\_$blan $k \&$ site $=$ bbb\#definition

20. NokiaSiemens(2008).www.nokiasiemensnetworks.com/global/AboutUs/Careers/Why+join+us/Employee+Engagement.htm?la nguagecode $=$ en

21. Blessing White (2008). The State of Employee Engagement, Blessing White

22. Gatenby, M., Rees, C., Soane, E., \& Truss, C. (2009). Employee engagement in context. London: Chartered Institute of Personnel and Development. 
23. Kang, M. (2010). Toward a model of engaging publics: Trust, satisfaction and identification, and the mediating role of public engagement between organization-public relationships and supportive behaviors. Unpublished doctoral dissertation, Syracuse University, Syracuse, NY.

24. Schuck, B., \& Wollard, K. (2010). Employee engagement and HRD: A seminal review of the foundations, Human Resource development Review, Vol. 9, No. 1, pp. 89-110.

25. Cook, S. (2012). The essential guide to employee engagement. Kogan Page.

26. Truss, C., Shantz, A., Soane, E., Alfes, K., \& Delbridge, R. (2013). "Employee engagement, organizational performance and individual well-being: exploring the evidence, developing the theory”, The International Journal of Human Resource Management, Vol. 24 No. 14, pp. 2657-2669. 
